\title{
Dissipation Kinetics and Distribution of Carbosulfan and its Toxic Metabolites in Banana, cv. Nendran (AAB)
}

\author{
S. Visveswaran ${ }^{1}$, Thomas George $^{1,2}$, S. Visal Kumar ${ }^{2}$, George Xavier $^{2}$, \\ L. Priya ${ }^{2}$, Sreya U. Parvathy ${ }^{1}$ and U. K. Priya ${ }^{3}$ \\ ${ }^{1}$ Department of Soil Science and Agricultural Chemistry, College of Agriculture, \\ Vellayani-695522, Kerala, India \\ ${ }^{2}$ All India Network Project on Pesticide Residues (AINPPR), College of Agriculture, \\ Vellayani, India \\ ${ }^{3}$ ICAR-Central Plantation Crops Research Institute, Regional Station, \\ Vittal - 574 243, Karnataka, India \\ *Corresponding author
}

\section{A B S T R A C T}

K e y w or d s
carbosulfan,
agrochemicals,
pesticide,
dissipation, residue,
banana

\section{Keywords}

carbosulfan pesticide dissipation, residue, banana

Article Info

Accepted: Available Online: 10 April 2021
The pattern of dissipation and persistence of carbosulfan and its metabolites in banana, cv. Nendran (AAB), with treatments as absolute control (No carbosulfan); recommended dose of per plant application of $400 \mathrm{mg}$ a.i. of carbosulfan, applied in the soil on 0,60 and 150 days of planting was conducted in red loam soils. The matrix matched samples of different plant parts (leaves, fingers bunches and flower bud, central core of pseudostem and corm) were spiked, and satisfactorily validated for residues extraction QuEChERS method. The plants parts analyzed for residue at predetermined time intervals had residue of carbosulfan in the $1^{\text {st }}$ to $4^{\text {th }}$ leaves till day $20^{\text {th }}$ and subsequent dissipation pattern prediction for BDL in 23.7 day indicated that, at recommended dose of application it is not safe to use the leaves within 23 days of application for serving or food packing (as commonly practiced in every households of Kerala).The residue of carbosulfan and their metabolites were in below detectable limit in blossom bud, flower bract alone, bunch on $15^{\text {th }}$ day of emergence, bunch on $30^{\text {th }}$ day of emergence, peel, bunch (fruit) on harvest, pseudo stem and corm, in recommended dose other additional doses. Metabolites of Carbosulfan residue existed in the $1^{\text {st }}, 2^{\text {nd }}$ and $3^{\text {rd }}$ leaves between $5^{\text {th }}$ and $20^{\text {th }}$ day and it dissipated to below detectable limit on $25^{\text {th }}$ day of application.

\section{Introduction}

Banana is one of the major fruit crops of India. It is consumed as fresh fruit and after cooking.
Inner core of the pseudostem, blossom bud and even the rhizome are edible. Carbosulfan is among the important pesticide used by farmers, especially for the control of aphids 
and weevil pests. Carbosulfan, (2,3-dihydro2,2-dimethyl benzo- furan-7-yl [(dibutylaminothio) sulfanyl] $\mathrm{N}$-methyl carbamate, a broad-spectrum systemic insecticide is recommended as a substitute for banned insecticides viz., phorate and carbofuran for the control of banana aphid, (the vector of bunchy top disease of banana) (KAU, 2011). The literature pertaining to the dissipation and movement of these chemicals in banana are scanty especially in Kerala. The study on the absorption, distribution, partitioning, and degradation pattern of carbosulfan in Nendran variety of banana in red loam acidic soils of Kerala, in the absence of data in acidic red loam soils also address safety concerns with respect to public health.

The metabolism of the insecticide carbosulfan to its carbofuran metabolite in oranges is rapid with dissipation of both pesticides in 3 days (Trevisan et al., 2004). Their residues concentrate in the bagasse (peel + flavedo + albedo) are not penetrating into fruit interior, thus are not contaminating the juice. There is lack of adequate data to fix the MRL of carbosulfan in banana. Vijayan (2000) studied the pattern of the absorption, and degradation of carbofuran in nendran variety of banana. A similar work on banana has not been taken out following introduction of 2 granular insecticides replacing the banned insecticide (KAU, 2011; 2015). Persistence and dissipation of granular pre-mix broad spectrum systemic fungicides trifloxystrobin and tebuconazole on banana and soil was studied by Beevi et al., (2013).

Carbosulfan when applied under invitro conditions in pakchoi (Brassica campestris) was transformed to higher toxic metabolites including carbofuran (CAN), 3hydroxycarbofuran (3-OH) and 3ketocarbofuran (3-KETO) where as in cucumber (Cucumis sativus L.), were metabolised only to CAN and 3-OH (Chai et al., 2015). In their study the degradation the time marking the disappearance of $50 \%$ of the pesticide less within 2.5 days and they suggested for the monitoring of metabolites as prior objective for carbosulfan, and different metabolites while assessing the risk of carbosulfan. None of the random samples analysed for presence pesticide residues in soils of banana growing tracts of different districts of Kerala, tested affirmative for carbosulfan (Paul et al., 2015).

Carbosulfan residue under laboratory conditions in black, red and alluvial soils following application @ 5 and $10 \mathrm{mg} \mathrm{kg}^{-1}$ progressively declined to below detectable level $\left(<0.01 \mathrm{mg} \mathrm{Kg}^{-1}\right)$ within 75 days in red and alluvial soil and 90 days in black soil. However, more than $95 \%$ of carbosulfan degraded within 60 days after incubation irrespective of the soil type and concentration (Rajeswaran et al., 2005).

\section{Materials and Methods}

Result of the soil analysis of a randomised block design (RBD) field experiment for investigating dissipation and distribution of carbosulfan and their metabolites in banana var. Nendran (AAB) in the red soils, kaolinitic isohyperthermic, typic kandiustults (GOK, 2007)at Instructional Farm of College of Agriculture, Vellayani, Thiruvananthapuram, Kerala, India showed a sandy loam textured with silt of 8.7and clay 19.5 percent respectively. Plot was moderately acidic with a $\mathrm{pH}$ of 5.7, electrical conductivity of 0.4 $\mathrm{dSm}^{-1}$, having medium organic carbon content of 1.5 percent, with high available $\mathrm{P}$ and $\mathrm{K}$ (196.1, 358.4 $\mathrm{kg} \mathrm{ha}^{-1}$ respectively).

Essential micronutrients levels in the soils were in sufficiency range for $\mathrm{Fe}, \mathrm{Zn}, \mathrm{Mn}$, and $\mathrm{Cu}$ extracted using dilute $\mathrm{HCl}$ ). However, the soil was deficient in secondary nutrients viz., $\mathrm{Ca}, \mathrm{Mg}$ and micronutrient $\mathrm{B}$ for which the 
crop were cultivated and managed as per popKAU, 2011 but for the study treatments as $\mathrm{T}_{\mathbf{1}^{-}}$ Absolute control (No application carbosulfan), $\mathrm{T}_{2}$ - Recommended practices $\left(\mathrm{RP}_{\mathrm{c}}\right)$ of $400 \mathrm{mg}$ a.i. of carbosulfan per plant, applied thrice viz., on 0,60 and 150 days of planting and $\mathrm{T}_{3-}$ Double dose of $\mathrm{RP}_{\mathrm{c}}$ (i.e., $\mathrm{RP}_{\mathrm{c} \times \mathrm{r}}$ 2), applied as per above schedule of $T_{2}$. For this purpose, Agricultural insecticide grade commercial carbosulfan granules (i.e., Sheriff $6 \% \mathrm{G}$ w/w manufactured and marketed by FMC India limited) was procured and used.

\section{Chemicals and reagents}

The analytical standards used were certified reference standards procured from Sigma Aldrich, Switzerland for Carbofuran (99.9\% w/w), Carbofuran-3-Keto (99.5 \% w/w), Carbofuran-3-hydroxy $(98.0 \% \quad \mathrm{w} / \mathrm{w})$ and Carbosulfan (98.5 \% w/w). HPLC grade solvents viz., acetone, ammonia solution, dichloromethane (HPLC grade); LC-MSgrade methanol and acetonitrile; AR grade magnesium sulphate, primary secondary amine, sodium chloride, sodium sulphate (anhydrous), calcium chloride anhydrous were used for residue analysis. Sodium sulphate, sodium chloride and magnesium sulphate were activated prior to use.

The celite and florsil-used were of chromatography grade, either of HPLC / LCMSor AR grades. Calibrated equipment and instruments were used to optimise the meet performance criteria. Commercially available granular form of carbosulfan (Sheriff 6\%G) formulation was used for soil application in the experimental plot.

\section{Instrumentation}

The Triple Quadrupole Mass Spectrometer (API 3200, AB Sciex, USA) attached to Ultra Performance Liquid Chromatograph (ACQUITY, Waters, USA) was used to analyse the clean extracts. The samples as well as standards were injected into the equipment for spectral matching and quantification of residues.

\section{LC-MS/MS System}

The chromatographic separation with Atlantis dC18 column (Waters, Ireland) with dimension $2.1 \times 100 \mathrm{~mm}, 5$ micron particle size, maintained at $40^{\circ} \mathrm{C}$ in the ACQUITY UPLC system of LC MS/MS. Elution was done using two eluents (solvent mixtures), viz., from reservoirs Aand $\mathrm{B}$ as described below

10 per cent methanol in water +0.1 per cent formic acid $+5 \mathrm{mM}$ ammonium acetate

10 per cent water in methanol +0.1 per cent formic acid $+5 \mathrm{mM}$ ammonium acetate

The optimized gradient elution for flow rate of the mobile phase solvent system with an initial flow rate of $0.80 \mathrm{~mL} / \mathrm{min}$ was obtained with 80 percent flow from reservoir $\mathrm{A}$ and 20 percentage from $\mathrm{B}$. The gradient elution of the compound mixture was monitored for 12 minutes.

The differential flow rates maintained for reservoir A being 80, 10, 5, 0, 80 and 80 percent at 4, 5, 9,10 and 12 minutes after injection with matching complementary flow rates from reservoir $B$.

The effluent from LC then enters into triple quadrupole API 3200 MS/MS system. System contains ion source gas 1 (at 50 psi), ion source gas 2 (at $40 \mathrm{psi}$ ) and curtain gas (at 30 psi) with ion source temperature of $550^{\circ} \mathrm{C}$ and ion spray voltage source of $5500 \mathrm{~V}$. The residues were quantified in MS/MS system. For each analyte, two selective reaction monitoring (SRM) transitions were taken in positive mode. 
Pesticide residues in the sample was calculated in $\left(\mathrm{mg} \mathrm{kg}^{-1}\right)$

Peak area of sample $x$

Concentration of standard injected $x$ Dilution factor

Peak area of standard

Laboratory experiments to determine the accuracy, relative standard deviation (RSD value), linearity and limit of quantitation (LOQ) of the methods followed for estimation viz., QuEChERS (Anastassiades, 2007) were carried out to ascertain the method to be followed for extraction of residues from the field samples.

The finely chopped samples pieces of $250 \mathrm{~g}$ per replicate was macerated in a blender. In 50 $\mathrm{ml}$ centrifuge tube, $10 \mathrm{~g}$ of the ground sample were taken in to which $20 \mathrm{ml}$ of HPLC grade acetonitrile was added and kept at ${ }^{-} 20^{\circ} \mathrm{C}$ for 20 minutes. The sample was then homogenised (Heidolph Silent Crusher-M) at $14000 \mathrm{rpm}$ for 3-4 min. To this $4.5 \mathrm{~g}$ of activated sodium chloride was added and vortexed for $2 \mathrm{~min}$ on a rotospin and then centrifuged for $5 \mathrm{~min}$ at $2,500 \mathrm{rpm}$. In to a $50 \mathrm{ml}$ centrifuge tube containing $5 \mathrm{~g}$ of pre-activated sodium sulphate, an aliquot of $12 \mathrm{ml}$ clear upper layer of the supernatant of the centrifuged sample was transferred and vortexed for $2 \mathrm{~min}$ for removing traces of moisture, if any. Dispersive solid phase extraction (DSPE) was for cleaned up. From this, $8 \mathrm{ml}$ of the upper layer was transferred in to a $15 \mathrm{ml}$ centrifuge tube containing $0.125 \mathrm{~g}$ PSA, $0.8 \mathrm{~g}$ anhydrous magnesium sulphate, $0.05 \mathrm{~g}$ end capped $\mathrm{C} 18$ and $0.025 \mathrm{~g}$ GCB. The mixture was again vortexed for $2 \mathrm{~min}$ and centrifuged for $5 \mathrm{~min}$ at 2,500 rpm. The $5 \mathrm{ml}$ of the centrifuged supernatant was transferred to turbovap tube maintained at $40{ }^{\circ} \mathrm{C}$ and 7.5 psi nitrogen flow using turbovap and evaporated to dryness. The residue was then reconstituted in $2 \mathrm{ml}$ of methanol and filtered through a 0.2-micron PVDF syringe filter $(13 \mathrm{~mm})$ was used for
UPLC-MS/MS analysis.

\section{Results and Discussion}

The percentage recovery of pesticide residue extracted using through QuEChERS method from banana leaves, pseudostem, bunch finger, flower, and corm collected (from the plants specially maintained in control plots) for carbofuran, 3-keto carbofuran, 3-hydroxy carbofuran and carbosulfan ranged from 80.0 to 119.9 percent, while the corresponding. According to Beevi et al., (2014), recovery values of pesticides in LC MS/MS ranged between 70-120 percent for 26 compounds tested, were considered to be satisfactory. The Linearity and Limit of Quantitation (LOQ) for recovery of residue from different parts of banana were was 0.01 to $1 \mathrm{ppm}$ and $0.01 \mathrm{ppm}$ respectively. The findings in the present study are in agreement with results of Bruzzoniti et al., (2014), Beevi et al., (2014), Lehotay et al., (2005) and Anastassiades et al., (2007) and these value for all different matrices of banana is as per SANTE (2015) norms. The MRM set up of quantitative ions for carbofuran, 3-keto carbofuran, 3-hydroxy carbofuran and carbosulfan were found to be 123, 151.1, 181.1 and 160.1 respectively. For qualitative ions the set-up, the respective parameters yielded 165.2, 179.1, 163.1 and 118.1 respectively. The retention time for carbosulfan and its metabolites were 3hydroxy carbofuran (1.06 $\mathrm{min})$, 3-keto carbofuran (1.52 min), carbofuran (1.94 min) and carbosulfan (5,36 min)

Field studies on dissipation (absorption, translocation, distribution, persistence) of carbosulfan in banana leaves

Carbosulfan and its metabolites were not detected in treatment $T_{1}$, control during the period of observation in all the four leaves tested (Table-2 and Fig-1). 
Table.1 Instrumental parameter setting and selection of SRM for quantitative and qualitative ions for carbosulfan and its metabolites in analyte matrix.

\begin{tabular}{|c|c|c|c|c|}
\hline \multirow{2}{*}{ Instrument parameter } & \multicolumn{4}{|c|}{ Molecule } \\
\cline { 2 - 5 } & Carbofuran & $\begin{array}{c}3 \text {-Keto } \\
\text { carbofuran }\end{array}$ & $\begin{array}{c}\text { 3-hydroxy } \\
\text { carbofuran }\end{array}$ & Carbosulfan \\
\hline Retention time in minutes & 1.94 & 1.52 & 1.06 & 5.36 \\
\hline Q1 Mass precursor ion & 222.1 & 236.1 & 238.1 & 381.2 \\
\hline $\begin{array}{c}\text { Q3 Daughter ion } \\
\text { (quantitative) }\end{array}$ & 123 & 151.1 & 181.1 & 160.1 \\
\hline Q3 Daughter ion (qualitative) & 165.2 & 179.1 & 163.1 & 118.1 \\
\hline $\begin{array}{c}\text { Declustering potential (Volt) } \\
\text { Collision energy(Volt) CE }\end{array}$ & 30 & 33 & 28 & 42 \\
\hline $\begin{array}{c}\text { Collision energyantitative) } \\
\text { (qualitative) }\end{array}$ & 29 & 23 & 16 & 22 \\
\hline $\begin{array}{c}\text { Collision cell exit potential } \\
\text { (Volt) CXP }\end{array}$ & 17 & 18 & 21 & 33 \\
\hline Entrance potential (Volt) EP & 10 & 10 & 10 & 1 \\
\hline $\begin{array}{c}\text { Collision cell entrance } \\
\text { potential (Volt) CEP }\end{array}$ & 26.3 & 22 & 24 & 31 \\
\hline
\end{tabular}

Table.2 Mean residue of total carbosulfan and its metabolites in $1^{\text {st }}$ to $4^{\text {th }}$ leaf of banana, $\mu \mathrm{g} \mathrm{g}^{-1}$

\begin{tabular}{|c|c|c|c|c|c|c|c|c|c|c|c|c|c|}
\hline \multirow{2}{*}{$\begin{array}{c}\text { Carbosulfan } \\
\text { in leaf } \\
\text { (position } \\
\text { from top) }\end{array}$} & \multicolumn{13}{|c|}{$\begin{array}{l}\text { Time interval in days } \\
\text { (No of days after completion of treatment dosing on } 150^{\text {th }} \text { day after planting) }\end{array}$} \\
\hline & $\begin{array}{c}\text { Before } \\
0^{\text {th } * *}\end{array}$ & $* * * 0^{\text {th }}$ & $1^{\mathrm{st}}$ & $3^{\text {rd }}$ & $5^{\text {th }}$ & $7^{\text {th }}$ & $10^{\text {th }}$ & $15^{\text {th }}$ & $20^{\text {th }}$ & $25^{\text {th }}$ & $30^{\text {th }}$ & $40^{\text {th }}$ & $50^{\text {th }}$ \\
\hline Control* & BDL & BDL & BDL & BDL & BDL & BDL & BDL & BDL & BDL & BDL & BDL & BDL & BDL \\
\hline $1^{\mathrm{st}}$ & BDL & BDL & BDL & BDL & 0.073 & 0.109 & 0.042 & BDL & BDL & BDL & BDL & BDL & BDL \\
\hline $2^{\text {nd }}$ & BDL & BDL & BDL & BDL & 0.057 & 0.075 & 0.252 & 0.053 & 0.027 & BDL & BDL & BDL & BDL \\
\hline $3^{\text {rd }}$ & BDL & BDL & BDL & BDL & 0.100 & 0.043 & 0.043 & 1.101 & 0.177 & BDL & BDL & BDL & BDL \\
\hline $4^{\text {th }}$ & BDL & BDL & 0.020 & 0.032 & 0.147 & 0.741 & 0.701 & BDL & BDL & BDL & BDL & BDL & BDL \\
\hline
\end{tabular}

Foot note: *mean of all metabolites for carbosulfan; **- $150^{\text {th }}$ day before treatment imposition and $* * *$ - 2 hours after $3^{\text {rd }}$ application and BDL-below detectable limit; ${ }^{\beta}$ carbosulfan and its metabolites; pop: - Package of practices

Recommendations: Crops, KAU 
Fig.1

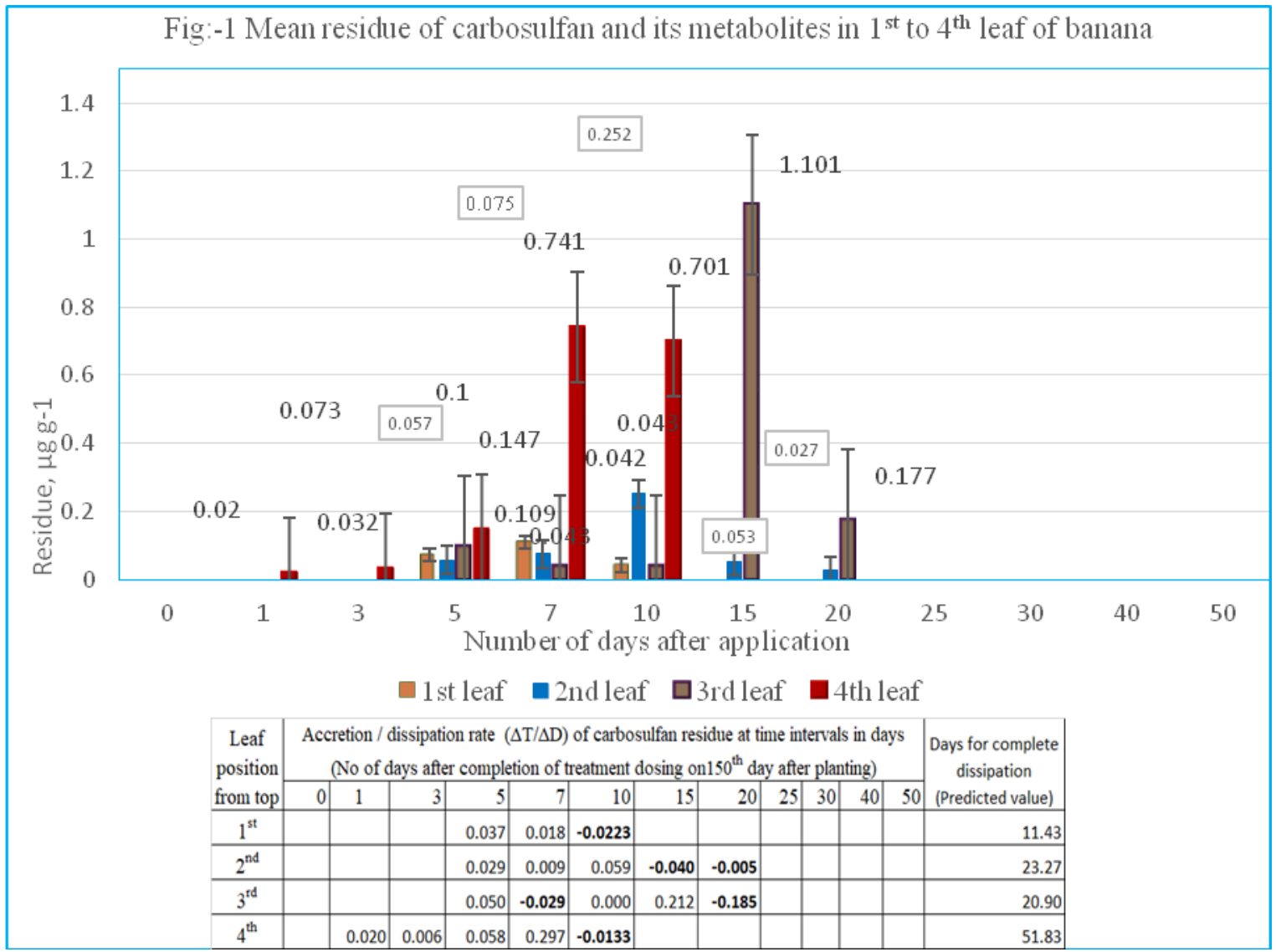

Absorption and persistence of mean of metabolites of carbosulfan displayed a different pattern in different leaves, though, residue of "carbosulfan molecule" was not detected in any of the tested samples during the sampling period in the $1^{\text {st }}, 2^{\text {nd }}, 3^{\text {rd }}$ and $4^{\text {th }}$ leaf of banana at both the levels of application(Table-2 and Fig-1).

Table -2 indicate that mean of residues of mean carbosulfan was present in all the leaf only between i.e.,"total carbosulfan" was observed only between $5^{\text {th }}$ and $10^{\text {th }}$ day of application. In the fourth leaf it was present between $1^{\text {st }}$ and $10^{\text {th }}$ day where as in $2^{\text {nd }}$ and $3^{\text {rd }}$ leaf it was between $5^{\text {th }}$ and $20^{\text {th }}$ day dissipating to BDL on day $25^{\text {th }}$. In first leaf residue of carbosulfan was detected only between $5^{\text {th }}$ and $10^{\text {th }}$ day and on day $15^{\text {th }}$ it was BDL. This clearly indicate early absorption translocation and accretion of metabolites to $4^{\text {th }}$ leaf. Vijayan (2000) reported in a residue study of carbofuran that average total carbofuran in $3^{\text {rd }}$ and $4^{\text {th }}$ leaf of banana was $0.027 \mu \mathrm{g} \mathrm{g}^{-1}$ on day $6^{\text {th }}$ and on all other days of observation, it was BDL. In the present study the spread of detection period of residue was same for $2,3^{\text {rd }}$ and $4^{\text {th }}$ leaf, however the translocation to $2^{\text {nd }}$ and $3^{\text {rd }}$ leaf was delayed further by 4 more days as compared to $4^{\text {th }}$ leaf.

The net transformation or dissipation rate per day as indicated by $\Delta T / \Delta \mathrm{D}$ worked out by dividing the difference in residue levels of the sample between two adjacent observations divided by the number of days in between the observation, was positive for $5^{\text {th }}$ and $7^{\text {th }}$ day indicating an accretion i.e., absorption rate being higher than rate of and transformation and dissipation of the molecule. On $10^{\text {th }}$ day it 
was negative indication a dissipation rate exceeding the absorption rate. Assuming a continued dissipation rate of day 10 , it could have dissipated completely by 11.9, 25.2, and 25.6 days in $1^{\text {st }}, 2^{\text {nd }}, 3^{\text {rd }}$ leaf (Fig-1).

However, in $4^{\text {th }}$ leaf the predicted day of complete disappearance was 51.83 days and was actually on BDL by $15^{\text {th }}$ itself, indicating much higher rate of dissipation in the system. A thresh hold value of accumulation of the residue molecule in the cell may be the factor that decide the rate of dissipation. The trash hold value of residue in the cells, in the absence of fresh absorption from the soil, may decide rate of dissipation.

Field studies on dissipation (absorption, translocation, distribution, persistence) of carbosulfan in bunches, fruits and other plant parts of banana

Residue of carbosulfan and its metabolites were also not detected in the blossom bud, flower bract alone, bunch (on $15^{\text {th }}$ day of emergence), bunch (on $30^{\text {th }}$ day of emergence), peel, bunch on harvest, pseudo stem and corm of banana.

Vijayan (2000) reported in a residue study of carbofuran that average total carbofuran in $3^{\text {rd }}$ and $4^{\text {th }}$ leaf of banana was $0.027 \mu \mathrm{g} \mathrm{g}^{-1}$ on day $6^{\text {th }}$ and on all other days of observation, it was BDL. Rouchaud (1990) reported that carbosulfan, furathiocarb and carbofuran were absorbed from soil by the plant with similar intensities, and the plant metabolized carbosulfan mainly into carbofuran and 3hydroxycarbofuran. According to Trevisan (2004) the carbosulfan metabolism to its carbofuran metabolite was rapid in 3 days, both analytes concentrated in the bagasse of oranges (peel + flavedo + albedo). Rajeswaran et al., (2005), too did not observe any residue of carbosulfan in cotton leaves at harvest, when applied on $25^{\text {th }}, 40^{\text {th }}$ and $55^{\text {th }}$ day after sowing at recommended dose as foliar spay.

In the $1^{\text {st }}$ leaf when applied at recommended dose mean residue of carbofuran (sum of all the metabolites) was highest on day $7^{\text {th }}$ $\left(0.741 \mu \mathrm{g} \mathrm{g}^{-1}\right)$ and was BDL on day $15^{\text {th }}$. The presence of carbosulfan in the $1^{\text {st }}$ to $4^{\text {th }}$ leaves till day $20^{\text {th }}$ and subsequent dissipation pattern prediction for BDL in 23.3 days indicated that, leaves of banana applied with carbosulfan is not safe for use within 24 days of application for serving or food packing (as commonly practiced in every house holds of Kerala). Application of carbosulfan as per package of practice recommendation is will not result in a development of residue in the harvested food products such as fruit, (both raw and ripe), flower bud, inner core of the pseudo stem and even in the corm.

\section{References}

Anastassiades, M., Scherbaum, E., Tasdelen, B., and Stajnbaher, D. 2007. Recent developments in QuEChERS methodology for pesticide multiresidue analysis. In: Ohkawa HM, Hisashi; Lee, Philip W (eds) Pesticide chemistry: Crop protection, public health, environmental safety. WileyVCH Verlag GmbH \& Co: KGaA. 439-458pp.

Beevi, S. N., Mathew, T.B., George, T., Nair, P.K., Rajith, R., and Xavier, G. 2013. Persistence and dissipation of granular premix broad spectrum systemic fungicides trifloxystrobin and tebuconazole on banana (Musa spp) and soil. Proceedings of national symposium on pest management in horticulture ecosystem. $128 \mathrm{p}$.

Beevi S.N., Paul. A., George.T., Mathew. T. M., Kumar. N. P., Xavier. G, Kumar. G.T.P., Rajith. R, Prathibha. K.R. and Kumar S.V. 2014 Pesticide. Residues 
in Soils under Cardamom Cultivation in Kerala, India. Pesticide Research Journal Vol. 26(1): 35-41.

Bonmatin, J.M., Giorio, C., Girolami, V., Goulson, D., Kreutzweiser, D.P., Krupke, C., Liess, M., Long, E., Marzaro, M., Mitchell, E.A., and Noome, D.A. 2015. Environmental fate and exposure; neonicotinoids and carbosulfan. Environ. Sci. Pollut. Res. 22(1) 35-67.

Bruzzoniti, M.C., Checchini, L., Carlo, R.M.D., Orlandini, S., Rivoira, L., and Bubba. M. D. 2014. QuEChERS sample preparation for the determination of pesticides and other organic residues in environmental matrices: a critical review. Anal. Bioanal Chem. 406: 4089-4116.

Chai, T., Zhao, H., Yang, S., Wang, M., and Qiu, J. 2015. Different transformation of carbosulfan to its higher toxic metabolites in pakchoi (Brassica campestris ssp.) and cucumber (Cucumis sativus L.) after field application. Int. J. Environ. Anal. Chem. 95(12): 1124-1133.

GOK. (Government of Kerala). 2007. Bench mark soils of Kerala. Soil Survey Organisation, Agriculture - Soil Survey Unit) Department. 83-87pp

KAU [Kerala Agricultural University]. 2011. Package of Practices Recommendations: Crops (14 ${ }^{\text {th }}$ Ed.). Kerala Agricultural University. Thrissur. 360p.

KAU [Kerala Agricultural University]. 2015. Development of Technologies including alternatives for Banned Pesticides for the Management of Pests and Diseases of Major Crops in Kerala. RKVY project report. Kerala Agricultural University, 61-63pp.

Lehotay, S.J., De, K.A., Hiemstra, M., and Bodegraven P.V. 2005. Validation of a fast and easy method for the determination of residues from 229 pesticides in fruits and vegetables using gas and liquid chromatography and mass spectrometric detection. $J$. AOAC. Int. 88(2): 595-614pp.

Mortensen, S.R., Holmsen, J.D and Weltje, L. 2015. Carbosulfan should not be categorized as a Bsystemic insecticide: a reply to Gibbons et al., (2015). Environ. Sci. Pollut. Res. 22:1725317254pp.

Paul, A., Beevi, S.N., Mathew, T.B., George, T., Prathibha, R., Neethu, S.K. and Mithra, I.V., 2015. Pesticide residues in soils of banana in Kerala. Journal of Insect Science (Ludhiana), 28(1), pp.68-71.

Rajeswaran, J., Santharam, G., Chandrasekaran, S., Jayakumar, R. and Kuttalam, S., 2005. Harvest Time Residues of Carbosulfan in Cotton Seed, Lint Oil and Soil. Annals Plant Protec. Sci.13(1): 145-148.

Sante. 2015. "Guidance document on analytical quality control and method validation procedures for pesticides residues analysis in food and feed." Document No. SANTE/11945/2015. Safety of food chain pesticides and biocides. European Commission, DirectorateGeneral for health and food safety.

Singh, N.V., Singh, S., and Kumar, J.2015. Efficacy of different insecticidal seed treatment against termite in wheat (Triticum aestivum L.) crop. J. Exp. Zool. 18 (1): 453-456. Singh et al., 2015.

Trevisan, M.J., Baptista, G.C.D., Trevizan, L.R.P. and Papa, G., 2004. Residues of carbosulfan and its carbofuran metabolites and 3-hydroxy-carbofuran in oranges. RevistaBrasileira de Fruticultura. 26(2): 230-233.

USEPA [United States Environmental Protection Agency]. 2009. 
Carbosulfan. Human Health Risk Assessment petition to support and maintain the established rice grain tolerance for imported rice. EPA 737F-96-005. Office of Pesticide programs. Washington DC, 2-38pp.

Vijayan, A.P. 2000. Carbofuran residues in banana. Ph.D. thesis, Kerala
Agricultural University, Thrissur, 57$150 \mathrm{pp}$.

Zhu, G., Wu, H., Guo, J., and Kimaro, F.M. 2004. Microbial degradation of carbosulfan in clay loam soil. Water, Air, and Soil Pollution. 153(1-4): 3544.

\section{How to cite this article:}

Visveswaran, S., Thomas George, S. Visal Kumar, George Xavier, L. Priya, Sreya U. Parvathy and Priya, U. K. 2021. Dissipation Kinetics and Distribution of Carbosulfan and its Toxic Metabolites in Banana, cv. Nendran (AAB). Int.J.Curr.Microbiol.App.Sci. 10(04): 639-647. doi: https://doi.org/10.20546/ijcmas.2021.1004.064 